\title{
VIEWPOINTS
}

\section{The Value of Islamic Guidance for Corporate Governance}

\author{
Kurt Lieberman *
}

Islamic guidance is a positive influence on humanity in numerous and diverse ways. In addition to its influence on individuals, Islamic guidance for good corporate governance provides a valuable, practical and business-relevant moral compass. For example, when a business incorporates maqasid values into its conduct, a better experience or outcome can usually be expected.

Islamic guidance for humanity helps individuals lead a better life. When individuals are part of an organisation, the environment in which they interact needs to be addressed as well. While individuals should strive to be positive and contribute to the improvement of humanity, creating a suitable climate makes the striving easier and more successful. Essentially, governance is the structure, mechanism, and culture that enables good things to happen. When there is good governance, the result can be a virtuous circle where good actions get reinforced and amplified.

Qur'anic guidance reveals that the noble status of khalifa, or God's steward on earth, is gifted to each man and woman so that they may be wholesome and constructive in their daily undertakings (Qur'an 2:29; 33:72). The purposes of what might be called "khalifa-ship" are elaborated in the standards of the maqasid al-Shari' $a$. The Qur'an further instructs that we are to be judged by our work (Qur'an 2:138). In other words, how we conduct ourselves - even in business has consequences for our stature in the eyes of God.

The maqasid provide context, purpose, and justification for rules of law. By connecting human rules enforced by authority with transcendent guidelines of more universal application and moral standing, the maqasid provide guidance on governance. The maqasid embody wisdom and seek the best interests of the people. They inform us concerning how to think about the law, rather than limiting us to narrow textual compliance. They provide space for human adjustment with the use of mercy, compassion, intuitive thought, and reasoning. They offer motivation and moral conviction more than mere obedience and 
mechanical conformity. They infuse our behaviours with an awareness of serving higher purposes.

Traditional corporate governance tends to focus on the shareholder relationship and sometimes the employee relationship. The guidance from the maqasid is broader and more complete as it addresses behaviour as opposed to just the nature of the desired relationship and all stakeholders of a company, including customers, employees, shareholders, suppliers, competitors, and the communities in which the company operates.

How can investors determine which companies are most aligned with the good purposes proposed by the maqasid? Both historically and in today's reality, many publicly traded companies engage in haram products, i.e. those things forbidden by Allah, for which Allah has provided something better. For example, Allah provides water or milk as better alternatives to alcoholic beverages. Magni Global Asset Management (Magni) conducts research to identify companies whose behaviour demonstrates that they are a better alternative. This research makes Magni different from other organisations producing Shari'a compliant equity portfolios. Most existing Shari'a compliant equity portfolios only remove the companies with haram products and/or financial structures.

Since we know that guidance from Allah is for the benefit of humanity, we know that the forbidden things are bad for us and the affirmative commands are good for us. How might we incorporate this knowledge into corporate governance? What is needed is a new approach, a new way of measuring company performance against the standards of the maqasid.

We expect companies that both avoid haram and adhere to Islamic guidance to perform better over time than companies that do not. Consequently, investment portfolios providing higher exposure to such companies should perform better over time than other portfolios, whether traditional Islamic portfolios or those that only perform Shari'a compliance to remove haram.

Good corporate governance, therefore, should strive to implement the standards of the maqasid. Governance is the task of implementing values in decisions. Governance requires at the start decisions about which values to honour and follow.

Should data show that companies adhering to Islamic guidance perform better over time, the latter could be used to improve traditional secular models of corporate governance. For example, a successful demonstration of better performance in Islamic finance creates a leadership opportunity for that sector within the financial services industry and in global discussions on corporate governance. Generally, a secular foundation leaves a gap between laws/ regulations and what people do (i.e. actual behaviour), avoiding ethical and/or moral requirements regarding what a company makes or distributes. 
Magni has developed a model and researched the data to test the value of Islamic guidance for corporations. The results of the test make an impressive business case for Islamic guidance in corporate governance. The model is called Islamic Stewardship and starts with Islamic guidance from the maqasid. The maqasid defines the desired relationship between people. Companies should foster these desired relationships between their employees and all stakeholders in the business.

Magni started with a secular corporate governance model. The implications of the maqasid were used to revise portions of the model and add new topics of research. An earlier paper called "Good is Good for Everybody: The Similarities of Corporate Governance across Faiths" (ICR 7, no. 3) explains the differences between the secular and the Islamic Stewardship assessments.

The Qur'an and Hadith have five values most relevant to companies and investing:
1. Amanah
(Trust)
2. 'Adl
3. Shurah
(Consultation)
4. Ijtihad
(Juristic reasoning)
5. Rahmah
(Mercy)

It is important to note that conventional financial metrics, such as net profits, dividends and share prices, are not considered when assessing a company against this model.

Magni researched the major public companies in the United States and scored each company against the Islamic Stewardship model. Specifically, Magni took the list of companies selected for inclusion from the Standard \& Poor's 500 Index of large capitalisation companies listed on the New York Stock Exchange and NASDAQ. The index is computed and published daily based on the market capitalisations of all companies it lists, thereby providing a benchmark for market valuation over time.

A little over half of the companies were deemed Shari'a compliant in their business operations. Each Shari'a-compliant company was assessed using the Islamic Stewardship Assessment and an overall Islamic governance score was determined. A hypothetical (model) stock portfolio was made, with each Shari'acompliant company receiving a weighting within the portfolio based on its score for good Islamic corporate governance against others in that portfolio. Higher scoring companies were allocated more money than lower scoring ones.

Then the hypothetical portfolio was sent to Morningstar Inc. for a mathematical comparison of its market returns over 10 years (for a period ending December 31, 2016) against the actual returns of the S\&P 500 over the same 10 years, as well as 
against the actual returns of the Shari'a-compliant subset of the S\&P 500 Index (S\&P 500 Shari'a).

The result was that the model portfolio outperformed the S\&P 500 Index and the S\&P 500 Shari'a.

Thus, if an investor had allocated money to a portfolio according to each company's Islamic Stewardship score, he or she would theoretically have made more money than if he or she had put the same amount into a fund tracking the S\&P 500 Index or the S\&P 500 Shari'a Index. ${ }^{1}$

The relevant measures of outperformance were:

\section{Excess return}

Excess return is the measure of higher returns per year earned by an investment compared to its benchmark.

In the case of the Magni model portfolio the Excess Returns were:

$7.83 \%$ over S\&P 500

$5.81 \%$ over S\&P 500 Shari'a

\section{Up Capture Ratio}

The Up-Capture Ratio is a measurement of how much more or less the investment earned in rising markets over the benchmark.

In the case of the model Magni portfolio, the Up-Capture Ratios were:

$118.33 \%$ over S\&P 500

$118.92 \%$ over S\&P 500 Shari'a

\section{Down Capture Ratio}

The Down Capture Ratio is a measurement of how much more or less the investment earned in falling markets over the benchmark.

In the case of the model Magni portfolio, the Down Capture Ratios were:

$84.00 \%$ over S\&P 500

95.02\% over S\&P 500 Shari’a

\section{Alpha}

Alpha is a statistical correlation between the returns of one investment against a benchmark. An Alpha number greater than zero indicates that the investment consistently out performs the benchmark. An Alpha of 5 or more is clearly attractive to investors. 
In the case of the model Magni portfolio, the Alpha correlations were:

7.07 over S\&P 500

4.75 over S\&P 500 Shari'a

\section{Beta}

Beta is a statistical correlation between the up and down volatility of one investment against a benchmark. A Beta number of 1 indicates that the volatility of the investment was similar to the benchmark. In other words, the risk of the investment was the same as investing in the portfolio taken as the benchmark.

In the cases of the model Magni portfolio, the Beta correlations were:

\subsection{3 over S\&P 500}

\subsection{9 over S\&P 500 Shari'a}

In other words, the Islamic Stewardship Portfolio outperformed the benchmark of both S\&P 500 and S\&P 500 Shari'a in returns for slightly more risk than the benchmark. High returns for comparable risk provides a superior investment strategy. Simply put, the test using the Islamic Stewardship portfolio showed that companies adhering to Islamic guidance outperformed companies that did not adhere as well. The test results are not surprising, but they are reassuring.

In conclusion, many successful companies already adhere to many aspects of Islamic guidance without specifically being aware of it. The maqasid provides excellent guidance on good governance. The aforementioned article "Good is Good for Everybody" demonstrates that religious faiths share common values and those values are associated with good governance. What Allah has told us is good, is good everywhere.

This research has many implications: companies have the opportunity to improve their business prospects and levels of success by adhering to good governance practices; employees should consider the quality of governance when they chose an employer; customers should buy from companies that are better governed.

Within the financial services industry, an opportunity exists for new investment products based on good governance. For investors, there should be demand for portfolios based on such governance. For leaders within Islamic finance, an opportunity exists to build new equity portfolios with a more complete incorporation of Islamic guidance. For academics and Shari'a scholars, there are new collaboration opportunities with secular counterparts.

Lastly, for Muslims there is pride and satisfaction that once again Allah has revealed a better way through Prophet Mohammed (p.b.u.h.). 


\section{Notes}

* Kurt Lieberman is the CEO of Magni, a US based research and asset management firm. Mr. Lieberman works to improve communities through social service, inner-city education, and welfare organisations. He would like to thank Stephen B. Young for assistance in the writing of this article.

1. Model portfolio calculations are based on quoted market prices and do not represent actual transactions. Results do not include transaction costs. It is not possible to invest directly in an index and products based on indexes may differ from index returns based on actual transaction costs and other expenses. Neither the Magni model portfolio nor the S\&P 500 Index returns include management expenses. 